\title{
AN ANALYSIS OF THE BURSARS' ACCOUNTS AT DURHAM CATHEDRAL PRIORY, 1278-1398
}

\begin{abstract}
This paper is based upon an examination of a selection of the bursars' accounts from Durham Cathedral Priory covering the period from the first extant account (1278-9) to the end of the 14th century. The accounts selected have been transcribed from the original documents and translated from Latin into English. A traditional focus of accounting historians in the medieval period has been on manorial accounting and the system of charge and discharge. This paper examines a series of non-manorial accounts and a variety of supporting accounting materials, analyzing them for evidence of the development and refinement of controls. After an introduction which reviews the background of the accounts and the extent to which they have been utilized for historical research, this paper describes the various sources of receipts and types of expenditure which are revealed. The format of the accounts is traced, and a review of total receipts and expenditure is conducted to gain an understanding of the overall financial position of the bursar's office. Next, the accounts are considered within the context of other accounting records to explore the financial controls in place. Finally, areas for further investigation and analysis are identified. The accounts selected reveal that actual receipts and actual expenditure were kept closely in tandem, and that an extensive network of other accounting material and documents allowing a system of cross-checks enabled auditors to ascertain the veracity and accuracy of the accounts.
\end{abstract}

\section{INTRODUCTION}

The bursars' accounts at Durham Cathedral Priory surviving from the period 1278 (the earliest surviving complete roll) ${ }^{1}$ to 1400 number in excess of 250 separate items, including some items which exist in duplicate and others that might be called subsidiary accounts and schedules. The bursars' formal accounts

${ }^{1}$ Fragments dating back to c. 1240 have been found [Piper, 1992, pp. 36-39].

Acknowledgments: The author is grateful to the Chapter of Durham Cathedral for access to Durham Cathedral Muniments, and wishes to thank Dr: B. Dodds, Mr. A. Piper, and the two anonymous reviewers for their valuable comments and suggestions. 
of the receipts and expenses of their office for this period cover some 85 years. These accounts and schedules vary enormously in size. Among the smaller items is an indenture issued in the year 1351-1352 witnessing the receipt of $£ 10.5 \mathrm{~s}$. by the bursar from the proctor of Norham (Illustration 1) that measures barely four inches by six inches. The account-roll of 1379-1380 would count among the larger items, being 11.5 inches wide and over 21 feet in length. Extracts from these rolls, edited by Fowler, were published between 1898 and 1901. However his selection was influenced by his interest in building work, and the extracts have been criticized as unreliable in detail [Lomas and Piper, 1989, p. 7], of little use for economic or statistical purposes [Knowles, 1955, p. 315], and confusing rather than clarifying Durham Cathedral Priory's financial organization [Dobson, 1973, p. 251].

The accounts are written on parchment with legibility and completeness varying extensively between accounts. Legibility may be affected by the faintness of the ink or by damage due to damp and other causes. Even by the 1430s, it was noted that many of the records "consumpti sunt, partim per pluviam, partim per ratones et mures" (have been destroyed, partly by rain, partly by rats and mice) [Dobson, 1973, p. 3]. These factors have had an impact on the selection of records for review and transcription. The accounts for 13 individual years have been examined along with supporting schedules. This sample cannot claim to be scientifically selected; the incidence of survival prevented the selection of an account on a regular basis every ten years. Incomplete rolls or those whose legibility were more problematic were passed over in favor of those more immediately decipherable. The objective was to examine an account-roll not too far removed from each of the decade ends between 1280 and 1400 . Although at the start of this period the selection is not so evenly spaced, from 1310 onwards the accounts selected are approximately ten years apart. A list of the accounts selected may be seen in Table 1. Additionally, a number of further accounts for consecutive years were examined in the expectation of gaining information on the treatment of balances carried forward from one period to the next.

The accounts are written in Latin and all monetary amounts are expressed in pounds, shillings, and pence (abbreviated as $€$., s., and d.). The Latin terms for these are libri, solidi, and denarii, and for halfpenny and farthing (one quarter of a penny) obolus and quarterius. One pound comprised 20 shillings and one shilling comprised 12 pence. 


\section{ILLUSTRATION 1}

\section{An Indenture from 1351-52}

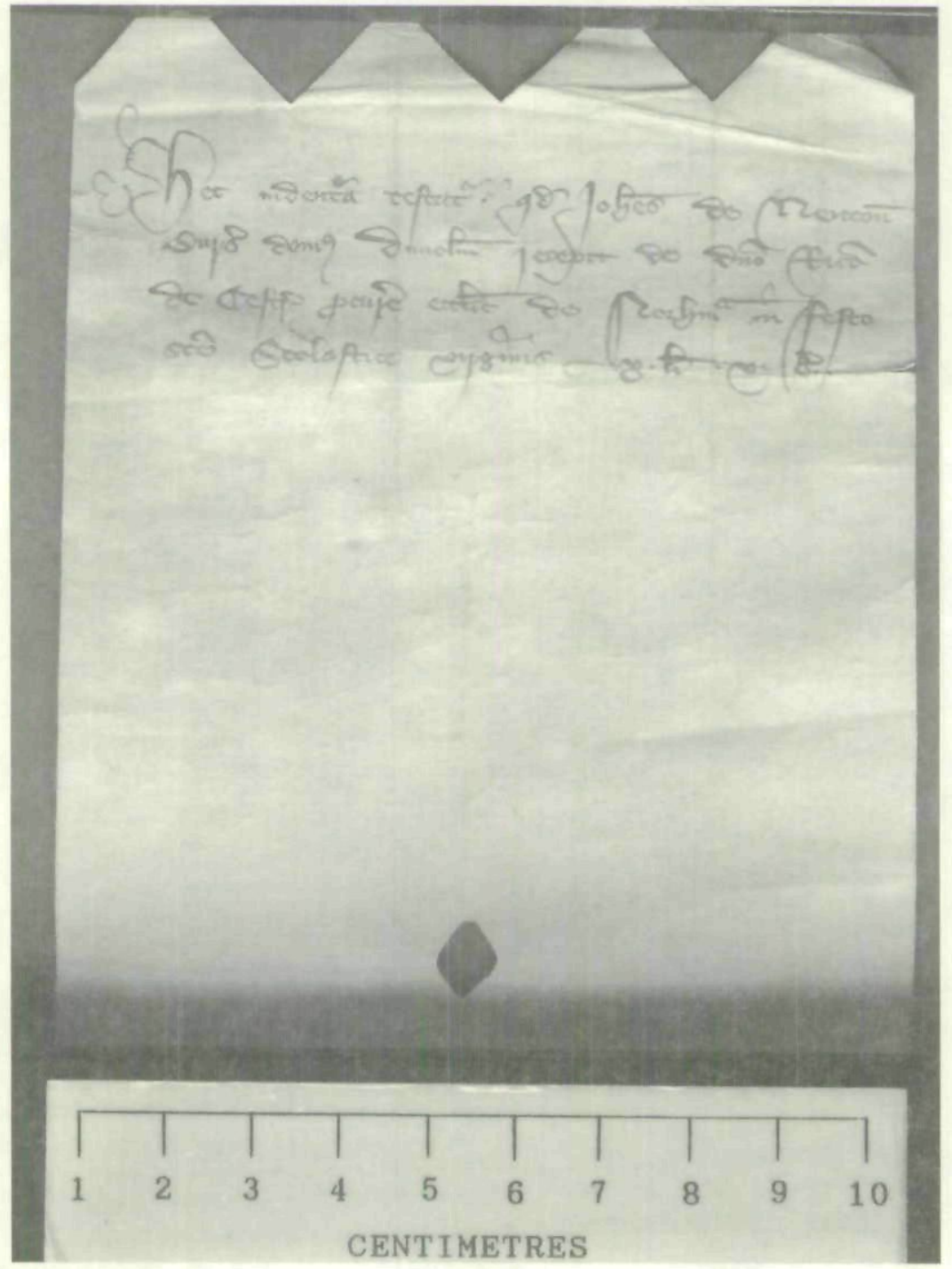

The bursar of Durham Cathedral Priory was one of a number of officials and obedientiaries of the house to whom was entrusted the overseeing or administration of a particular section of the priory's activities. Thus, the chamberlain was responsible for clothing the monks, and the sacristan for caring for 
the altar vessels and supervising matters such as lighting within the church. Customarily in Benedictine houses, the officials or obedientiaries controlled certain streams of income sufficient to enable them to perform their role [Knowles, 1969, p. 109]. The details of such allocations are still available for a number of houses such as Abingdon Abbey [Moorman, 1945, p. 281] and Bury St. Edmunds [Snape, 1926, pp. 24-26]. At the conclusion of each period in office, each obedientiary was required to provide a written account or compotus detailing all monies received and expenses incurred. At Durham, accounting material survives from the offices of the bursar, terrar, cellarer, almoner, chamberlain, communar, feretrar, hostillar, infirmarer, and sacrist, as well as accounts from the manors owned by the priory; accounts for livestock and mines; accounts from proctors responsible for the administration of the priory's possessions lying further away in Scotland, Northumberland, and Yorkshire; and, finally, accounts from the cells or dependencies of Durham Cathedral Priory, such as the priories of Coldingham and Finchale. ${ }^{2}$

The bursar is described in the Rites of Durham, written in 1593 , as controlling all the receipts and expenses of the house [Fowler, 1903, p. 99]. However, based on a review of the financial records, Dobson [1973, pp. 257-260] disputes this, although agreeing that the bursar did control over two-thirds of the total throughout the period between 1300 and the Dissolution. He also quotes the practice of the priors, when required to produce the overall accounts of the house, in delivering the bursar's roll alone. A more precise ratio will require future analysis of the other remaining accounting records of Durham Cathedral Priory.

The account-rolls of Durham Cathedral Priory provide a rich source of information for the 13th through the 16th centuries, and have provided an important foundation for a number of studies. The majority of these studies either concerned single issues or related to the period after 1400. Halcrow [1949] concentrated on the administration and agrarian policy of the manors of Durham Cathedral Priory. Dobson [1973] concentrated on the priorate of John Wessington (1416-1446) and the first half of the 15th century. More recently, Cambridge [1992] has focused on the building works of Durham Cathedral Priory between

${ }^{2} \mathrm{I}$ am indebted to Mr Alan Piper for the use of the handlist which he has compiled listing the medieval accounting material found in the muniments of the Chapter of Durham Cathedral. Most of the information contained in this handlist is available at http://flambard.dur.ac:6336/dynaweb/handlist/ddc/dcdmaccs/. 
1339 and 1539; Dodds [2002] has focused on tithe and agrarian output between 1350 and 1450; and Threlfall-Holmes [2005] has used the accounts for an analysis of the purchasing strategies of the priory between 1460 and 1520 . Elsewhere, detailed studies which draw upon surviving accounts to investigate monastic economy and administration include those on Bolton Priory [Kershaw, 1973], Canterbury Cathedral Priory [Smith, 1943], Norwich Cathedral Priory [Saunders, 1930], Westminster Abbey [Harvey, 1977, 2002], and St. Swithun's Priory at Winchester [Kitchin, 1892]. Additionally, accounts have been transcribed and published from Worcester Priory [Wilson and Gordon, 1908; Hamilton, 1910]. A more general survey of English monastic finance was undertaken by Snape in 1926, and, more recently, Knowles [1940, 1948, 1955] included an analysis of monastic administration, management, and finance in his histories of the monastic and religious orders in England.

From accounting historians, the output has been less prolific. As Jack [1966, p. 137] observed, medieval accounting has tended to be overlooked except in so far as the origins and early development of the double-entry system may be traced. Chatfield [1977, pp. 19-31], in his chapter on medieval account keeping, described both government and manorial accounting and the importance of the agency relationship. Harvey [1999] has analyzed the forms of written manorial accounts and identified three broad phases in the development of written manorial accounts (see below). Concepts of profit have been explored by Stone [1962] and Postles [1994], and arrears and the excessus balance have been examined by Postles [1981] and Noke [1994]. These studies have been overwhelmingly concerned with manorial accounts. This paper, in contrast, is based upon a series of bursars' accounts and related documentation.

\section{SOURCES OF RECEIPTS AND TYPES OF EXPENDITURE}

The various sources of receipts and types of expenditure are described to demonstrate the number and variety of transactions which required monitoring and recording. The major sources of receipts can be seen in Table 1. They may be classified into four types: rents, labor, and customary dues from tenants living on lands owned by the priory; tithes due from appropriated parishes; various other receipts; and, finally, borrowings.

The rents from lands, mills, and fisheries due to the priory from its estates appear to have fallen due twice a year at Pentecost and Martinmas, although a rent was not considered over- 


\begin{tabular}{|c|c|c|c|c|c|c|c|c|c|c|c|c|c|c|c|c|c|}
\hline 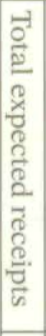 & 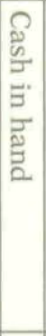 & 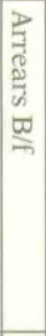 & $\begin{array}{l}\overrightarrow{0} \\
\frac{2}{E}\end{array}$ & 高 & 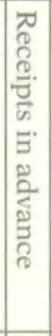 & . & 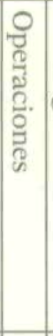 & 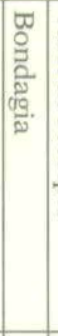 & 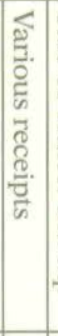 & 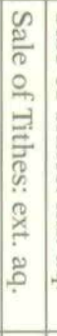 & 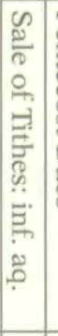 & 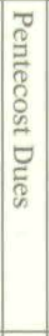 & 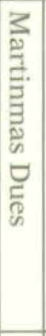 & & & 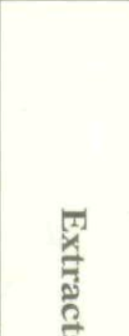 & \\
\hline $\begin{array}{l}\vec{\circ} \\
\stackrel{2}{2}\end{array}$ & 2 & $\overrightarrow{\vec{v}}$ & ๖్ & 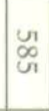 & ' & ' & . & ' & . & , & 1 & $\overrightarrow{\bar{\omega}}$ & 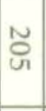 & in & $\begin{array}{l}\vec{N} \\
\sim \\
\infty \\
\dot{1} \\
0 \\
\end{array}$ & 홍 & \\
\hline$\underset{N}{\omega}$ & , & $\begin{array}{l}\vec{\omega} \\
\stackrel{\infty}{ }\end{array}$ & $\underset{\sim}{\sim}$ & ' & ' & $\begin{array}{l}w \\
\ddagger\end{array}$ & 1 & ' & $\overrightarrow{0}$ & $\mid \begin{array}{c}\infty \\
⿱ 亠 乂 \\
\perp\end{array}$ & $\begin{array}{l}\omega \\
\infty \\
\infty\end{array}$ & ్ㅠㅇ & 융 & is & $\begin{array}{l}\vec{n} \\
0 \\
N \\
\dot{b} \\
w\end{array}$ & $\begin{array}{l}\vec{\sigma} \\
\tilde{\sigma}\end{array}$ & \\
\hline $\begin{array}{l}\text { 岕 } \\
\text { a }\end{array}$ & , & $\underset{\sim}{N}$ & $\underset{\Xi}{.}$ & , & ' & ' & ' & ' & $\underset{v}{\vec{w}}$ & $\underset{\omega}{w}$ & $\mid$ & $\underset{\omega}{\omega}$ & 峁 & is & 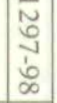 & 总 & \\
\hline$\frac{9}{8}$ & ' & w & $\frac{\tilde{a}}{\dot{a}}$ & ' & ' & $\overrightarrow{U_{\infty}}$ & ' & ' & N్ & 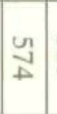 & $\begin{array}{l}w \\
\mathbb{U}\end{array}$ & $\underset{\leftarrow}{w}$ & $\underset{\omega}{\omega}$ & in & \begin{tabular}{|c|}
$\bar{\omega}$ \\
$\dot{0}$ \\
$\vdots$ \\
\end{tabular} & 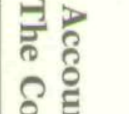 & \\
\hline $\begin{array}{l}\vec{\omega} \\
\overrightarrow{0}\end{array}$ & , & $\vec{v}$ & $\underset{\underset{\omega}{\sim}}{\vec{w}}$ & ' & ' & $\simeq$ & 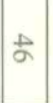 & ' & $\frac{N}{0}$ & 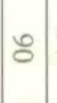 & $\begin{array}{l}n \\
\mathbb{E}\end{array}$ & $\underset{w}{w}$ & $\underset{\omega}{w}$ & its & $\begin{array}{c}\bar{\omega} \\
\infty \\
\frac{1}{\sigma}\end{array}$ & 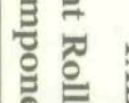 & $\frac{1}{2}$ \\
\hline $\begin{array}{l}\mathbf{N} \\
\text { 。 } \\
\text { D }\end{array}$ & . & $\overrightarrow{\tilde{\omega}}$ & छे & , & 峜 & $\underset{\underline{v}}{\underline{\sigma}}$ & N & , & $\underset{\infty}{\omega}$ & $\frac{N}{n}$ & $\underset{\infty}{\infty}$ & $\begin{array}{l}n \\
\vdots \\
u\end{array}$ & $\begin{array}{l}\tilde{N} \\
\infty\end{array}$ & का & 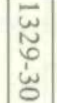 & $\begin{array}{ll}\overrightarrow{0} & 0 \\
0 & 0\end{array}$ & (7) \\
\hline $\overrightarrow{\mathrm{J}}$ & ' & $\vec{a}$ & $\underset{\sim}{\vec{a}}$ & , & $\stackrel{+\infty}{\infty}$ & $\overrightarrow{ \pm}$ & ' & ' & $\begin{array}{l}\vec{\infty} \\
+ \\
+\infty\end{array}$ & 疋 & $\vec{\circ}$ & $\underset{N}{\omega}$ & $\underset{\sim}{w}$ & th & $\begin{array}{l}\bar{w} \\
w \\
\omega \\
\omega \\
\omega\end{array}$ & 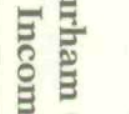 & \\
\hline$\underset{\text { ज }}{\vec{\Delta}}$ & ' & స్心 & $\frac{\vec{N}}{N}$ & , & $\rightarrow$ & $\tilde{O}$ & ' & ' & 용 & $\stackrel{\circ}{\omega}$ & $\infty$ & w & $\frac{\omega}{N}$ & it & $\mid \begin{array}{c}\vec{w} \\
\vec{t} \\
\dot{0} \\
\dot{o}\end{array}$ & Е & \\
\hline 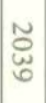 & , & $\underset{\infty}{\infty}$ & $\overrightarrow{8}$ & ' & ' & స్ & $\vec{N}$ & 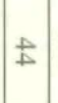 & $\begin{array}{c}\tilde{\omega} \\
\mathbf{\omega}\end{array}$ & $\cup_{1}$ & 点 & $\underset{w}{w}$ & $\underset{\sigma}{\mathbb{N}}$ & in & $\mid \begin{array}{l}\vec{w} \\
\tilde{n} \\
0 \\
\dot{\sigma}\end{array}$ & כ) & \\
\hline $\begin{array}{l}\text { N } \\
\stackrel{\infty}{N}\end{array}$ & . & $\begin{array}{l}\bullet \\
\text { U్ }\end{array}$ & $\underset{\perp}{\vec{N}}$ & , & ' & ' & $\stackrel{+}{\infty}$ & 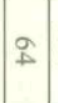 & $\underset{\sim}{v}$ & $\bar{\omega}$ & $\mid \begin{array}{l}N \\
\vdots \\
+\end{array}$ & $\begin{array}{l}w \\
\tilde{y}\end{array}$ & $\underline{\underline{w}}$ & it & $\begin{array}{l}\bar{w} \\
\alpha \\
0 \\
\dot{b}\end{array}$ & $\frac{9}{N}$ & \\
\hline $\begin{array}{l}\text { w } \\
\text { \& } \\
\text {. }\end{array}$ & ' & $\underset{\text { 売 }}{\vec{N}}$ & $\begin{array}{l}\text { N } \\
\text { Ju } \\
\text {. }\end{array}$ & ' & , & $\underset{N}{N}$ & $\$$ & $\stackrel{\infty}{\omega}$ & Ñ & $\because$ & $\vec{v}$ & $\underset{w}{\sigma}$ & 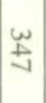 & it & $\begin{array}{c}\vec{W} \\
\text { ర } \\
0 \\
0\end{array}$ & $\begin{array}{l}\infty \\
\stackrel{1}{\omega} \\
\omega_{0}\end{array}$ & \\
\hline$\underset{\omega}{\omega}$ & ' & $\vec{a}$ & $\vec{a}$ & , & ' & $\vec{\sim}$ & \pm & 0 & \begin{tabular}{|}
$w$ \\
$\omega$ \\
$\Phi$
\end{tabular} & రె & 命 & $\underset{\tilde{u}}{\sigma}$ & $\underset{\tilde{c}}{\tilde{c}}$ & in & $\begin{array}{l}\vec{w} \\
\infty \\
0 \\
\dot{\delta}\end{array}$ & & \\
\hline $\begin{array}{l}\text { w } \\
\stackrel{\text { I }}{ \pm}\end{array}$ & ' & 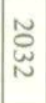 & $\overrightarrow{\vec{a}}$ & ' & ' & ' & $\underset{\infty}{\omega}$ & ঃ & $\stackrel{ \pm}{a}$ & $\begin{array}{l}\infty \\
0\end{array}$ & $\begin{array}{l}\mathbb{N} \\
\mathbb{N} \\
N\end{array}$ & $\begin{array}{l}\omega \\
\mathbb{t} \\
\end{array}$ & $\underset{\sim}{\underline{\sim}}$ & का & $\begin{array}{l}\vec{w} \\
0 \\
\vec{b} \\
\dot{b} \\
\infty\end{array}$ & & \\
\hline
\end{tabular}


due until the subsequent due date had arrived [Lomas and Piper, 1989 , p. 11]. Pentecost is a moveable feast which falls seven weeks after Easter. Martinmas falls on November 11. Other receipts, such as wodladpennies, due at Pentecost and presumed to be in lieu of labor in the woods or loading or providing wood, arose on only one of the due dates [Fowler, 1900, p. 988; Lomas and Piper, 1989, p. 221]. With the exception of the years 12781279 and 1329-1330, the total due at Pentecost and Martinmas seems to have remained within a consistent band of $£ 300$ to $£ 350$.

However, tithe income, as might be expected, was more volatile. In each parish a tithe or tenth of all production was payable to the parish priest. ${ }^{3}$ Durham Cathedral Priory controlled a number of parishes and was entitled to their tithes, which were payable in kind, and the bursars' accounts reflect either the sale of the produce received or the sale of the right to receive the produce. Tithes infra aquas arose from the area between the Tyne and the Tees; those from further away were labeled extra aquas. The volatility of tithe income in the accounts reflects not only the fluctuations in harvests, but also decisions as to how much to sell and how much to consume.

Varie recepte (various receipts) included receipts from more distant lands administered by a proctor, such as those in Scotland and Norham; profits from the halmote and free courts; and sales of wool, corn, livestock, and wood. Again, varie recepte comprised a volatile source of receipts, a volatility which reflected decisions such as whether stock should be held or sold and the prevailing market prices. Operaciones and bondagia made their appearance in the accounts under their own headings as customary labor dues commuted for money payments.

Mutuaciones (borrowings) appear regularly throughout the accounts, again showing great volatility from year to year, as do premanibus (payments received in advance). Both on occasion form a significant proportion of receipts for the year. The accounts identify the source of the loan by the name or position of the lender but provide little other information as to the term and conditions of the loan. Some loans were raised internally from the prior and other officials of the house; others came from external sources such as those from the dean of York in 1292-1293 or from the wool merchant Thomas del Holme in 1329-1330.

\footnotetext{
${ }^{3}$ Moorman [1945, pp.115-116] provides an outline of the origins of the system of tithing and of its rigorous enforcement.
} 
The types of expenditure incurred by the bursar's office are summarized in Table 2. Garderoba (wardrobe) included expenditure on clothing for the monks' retainers and servants, and spices and delicacies for the refectory table. Purchases of livestock were listed by category: horses, cattle, pigs, lambs, and sheep. Purchases of grain included wheat, malt, ale, oats, peas, and beans. Marescalia comprised horse-related expenditure. Expense necessarie (necessary expenses) could include parchment, slippers, boots, locks, barrels, and serving vessels among other items; and minute expense (small expenses) included smaller amounts for items such as the carrying of letters. Contribuciones (contributions) reflected the demands of royal and papal taxation. Tithe expenses recorded the costs of collecting, transporting, and storing tithes. Condonaciones represented the waiving of amounts due to the priory from its tenants. Tallies typically comprised payments to the cellarer for the purchase of provisions for the sustenance of the brethren, and to the servientes (officers who supervised the manors on behalf of the priory) for the payments necessary in the day to day administration of the manors.

The categories of receipts and expense outlined above neither constitute an exhaustive list nor do they appear in every account-roll. On occasion, the headings change, but the variety illustrates the complexity and number of cash transactions entailed in the administration of Durham Cathedral Priory.

\section{THE FORMAT OF THE ACCOUNTS}

Harvey [1999, pp. 25-40] has analyzed the forms of written manorial accounts and identified three broad phases in the development of written manorial accounts: an early phase (c. 1200 -c.1270) with diverse forms; a second period (c.1270-c.1380) that featured great standardization and detail; and a final phase (c.1380-c.1530) in which the accounts are less detailed. This next section analyzes the form of the bursars' accounts at Durham Cathedral Priory, examining the titles given at the head of the accounts, the order of items within, and the use of headings and totals.

The title of an account could be written in a plain hand or elaborately on occasion. Illustrations 2 and 3 provide examples from the rolls of 1278-1279 and 1390-1391. The first existing account of 1278-1279 is headed "Compotus W. de Norton a die Sancti Wilfridi in Hyeme anno gracie mcclxx octavi usque in diem Sanctorum Processi et Martiniani" (The account of Walter 


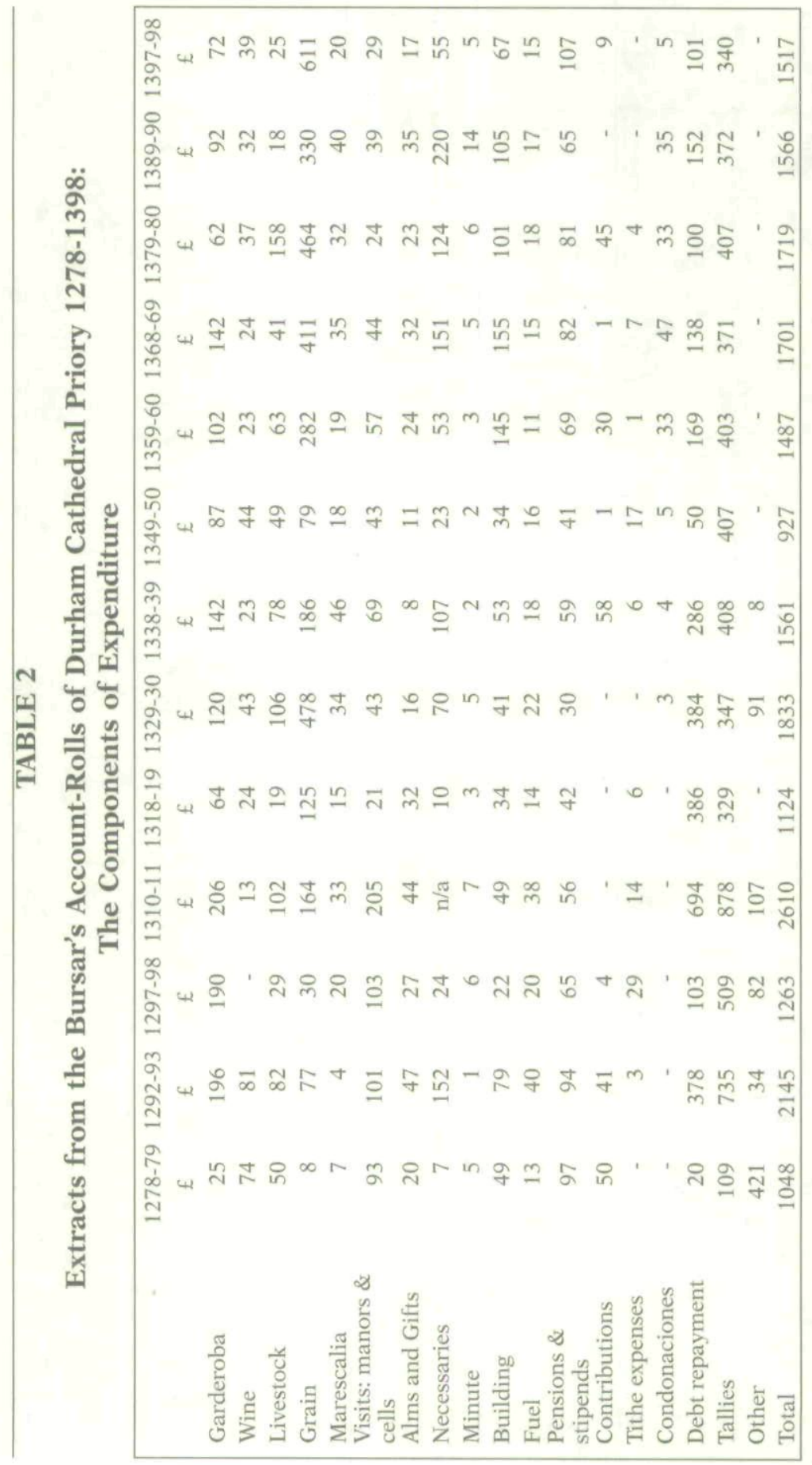




\section{ILLUSTRATION 2}

\section{The Head of the Account-Roll of 1278-79}

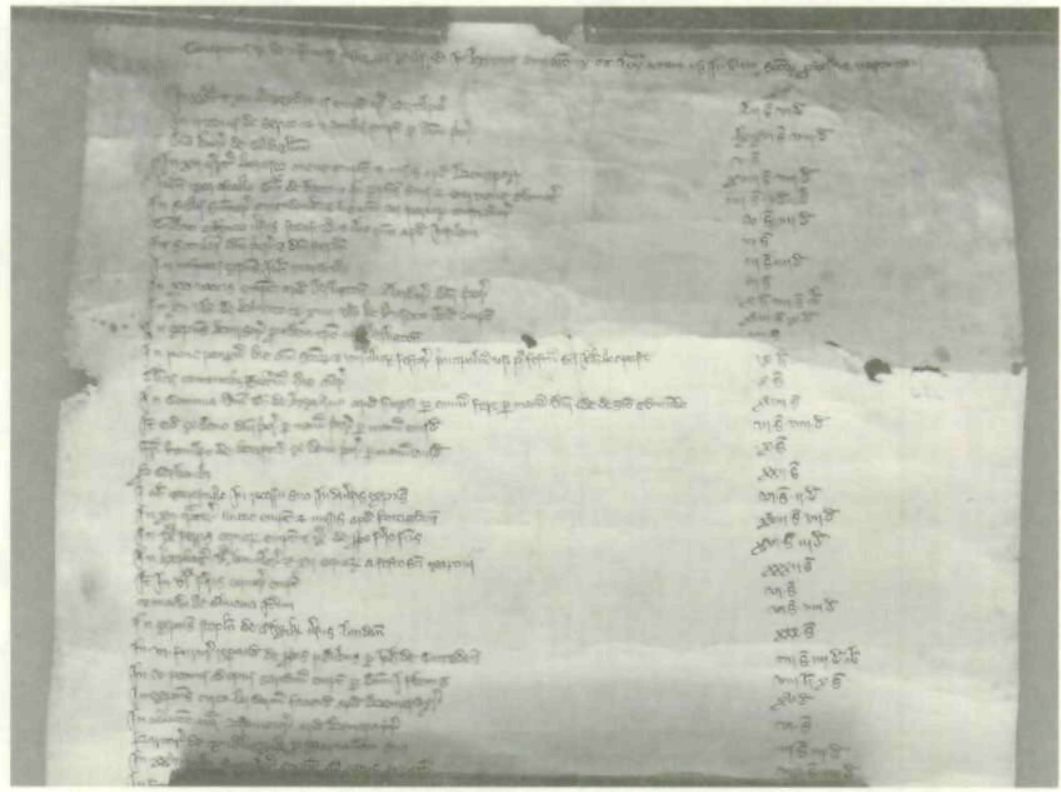

of Norton from St Wilfred's day in winter in the year of grace 1278 to the day of Saints Processus and Martinianus). ${ }^{4}$ The next extant account lacks the start date of the account: "Compotus fratris $R$. de Mordon Bursarii Dunelmensis die lune proxima post festum beati michaelis archangeli anno gracie mcc nonagesimo tercio" (The account of Ralph of Mordon on the Monday next after the feast of the blessed Archangel Michael in the year of grace 1293), but it does specify that the person in whose name the account is prepared holds the office of bursar of Durham. This indicates a desire to aid those reviewing accounts to be certain as to what they were seeing, and to enable them to find the correct account more quickly. In later years, it is usual for both the start and end dates of the account to be given. The roll of 1310-1311 is entitled "Compotus domini Thome de Hesswell bursarii a domenica proxima post festum sancti michelis anno domini millesimo cccx usque ad festum santi martini anno domini millesimo cccxi pro annum integrum et vi septimanas"

${ }^{4}$ The Latin of the accounts is often in abbreviated form. In quotations from the account-rolls, apart from cash items where li, s, d, ob, and q have been retained, the Latin has been extended. 
(The account of Dominus Thomas of Haswell, bursar, from the Sunday next after the feast of St. Michael in the year of our lord 1310 until the feast of St. Martin in the year of our lord 1311, for a full year and six weeks). Thus, it is clearly explained that this

\section{ILLUSTRATION 3}

\section{The Head of the Account-Roll of 1390-91}

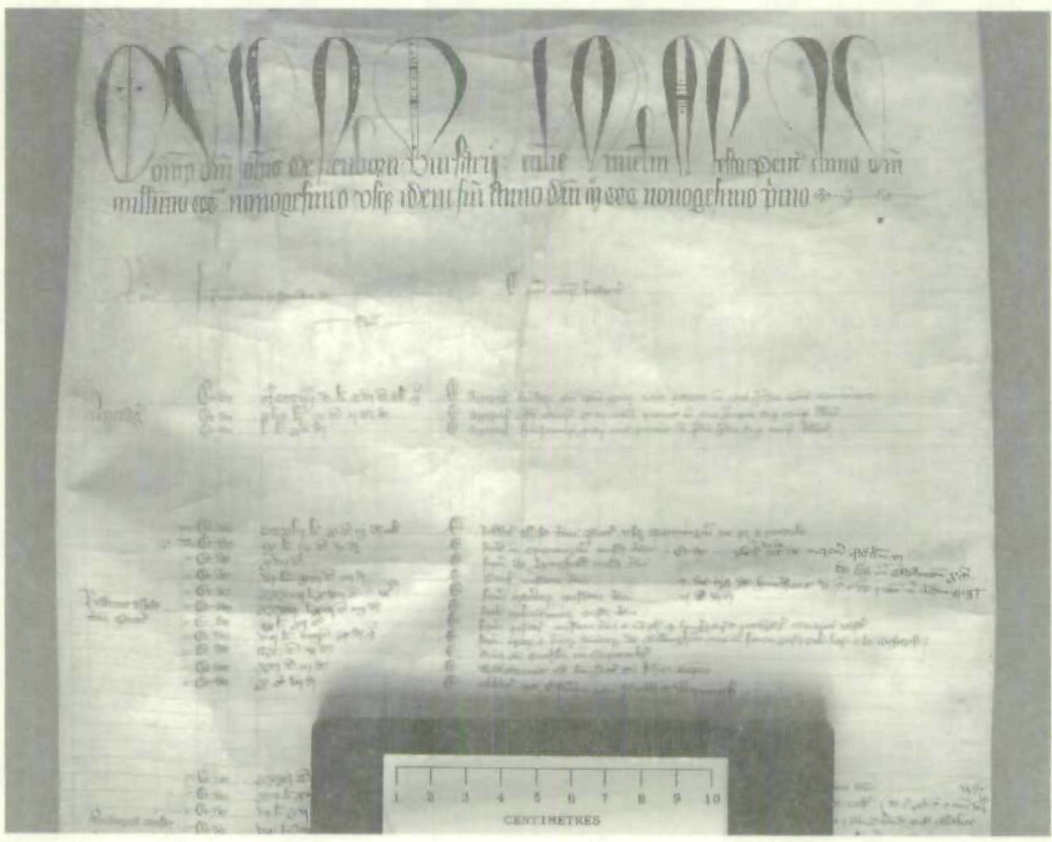

account runs from October 4, 1310 to November 11, 1311 for a period in excess of a year.

The period covered by each account is typically for a full year, but if the office-holder changed during the year, an account was prepared up to the date of departure. This illustrates the personal nature of the office and of the associated accountability, in keeping with traditional charge and discharge statements. The office itself was not required to prepare accounts for a certain period on a certain date. For example, it seems that on January 9, 1317, only nine weeks after an account was rendered for the year to November 11, 1316, Alexander of Lamesley submitted another set of accounts for the nine weeks, having been replaced in office by John of Harmby who then presented a set of accounts covering the period January 9, 1317 to January 8, 1318. Account-rolls with a year-end of Martinmas 
(November 11) are found regularly until 1360 . Thereafter, Pentecost was common until 1374, Michaelamas (September 29) until 1388 , and Pentecost again until 1398. The period covered by an account-roll often tends to reflect the date on which a bursar assumed office rather than a consistently imposed date.

Within the accounts can be discerned a gradual formalization. The first account of 1278-1279 commences with a list of individual expenses not grouped by category and not arranged in any apparent order. Foodstuffs, clothing materials, cash payments, travel expenses, livestock purchases are all itemized in a seemingly random order with an occasional sub-total. However, after approximately 130 entries, a heading expense prioris extra (expenses of the prior outwith the priory) does appear. Beneath this heading are listed the expenses incurred as he visited the priory manors, followed by a sub-total labeled summa coquina extra (total of external kitchen expenses). The account-roll continues with purchases of wine and fuel; some payments pro pace facta (for making peace, or settling a dispute); single entries for the payments of pensions and stipends at Martinmas and at Pentecost; and ends with expense per tallias de maneriis et aliis (expenses by tally to the manors and others). The expenses section concludes with summa totalis expense (sum of all expense). Receipts are then considered in a section which is much shorter than the expenses section and comprises only some 34 lines. This starts with In bursa (in the purse, i.e., cash left over from the account of the previous year), followed by a list of receipts some of which are evidently summarized totals and others individual amounts. The first receipt, recepte per magnum cirographum (receipts from the great chirograph ${ }^{5}$ ), relates to receipts of arrears. Unfortunately, the great chirograph has not survived, but it appears to have been a document upon which were recorded all arrears due to the priory. This is followed by recepte de rotulo sancti martini and recepte de rotulo Pentecosti (receipts from the rent-rolls of Martinmas and Pentecost). From the proctors of the estates in Northumberland and Scotland are received amounts with and amounts without a supporting chirograph. Then a total of receipts is given, followed by et sic remanent in bursa (and so there remains in the purse). Within the account, expenses have been totaled, cash held at the start of the account has been added to receipts for the period, and from this the total expenses have been subtracted to arrive at a cash total carried forward. These references to amounts held in the purse are not

${ }^{5} \mathrm{~A}$ chirograph is a formal handwritten document. 
present in subsequent accounts.

The second extant account is from 1292-1293, has a grander and more florid title, and is more clearly ordered and makes much greater use of headings. The account deals first with receipts and then with expenses, a pattern repeated in all the subsequent accounts surveyed.

The roll begins by listing all the arrears and debts due to the house at the start of the period for which the bursar has responsibility for collecting. That these sums refer to all amounts due rather than to cash sums actually received is indicated by two factors. First the phrase, "Idem reddit compotum de dccxlvi li iiiis viid ob de omnibus contentibus in cyrograffo usque in diem Sancti Martini anno domini mcc nonagesimo secundo" (The same person, i.e., the bursar Ralph of Mordon, renders account for $£ 746.4 \mathrm{~s} .71 / 2 \mathrm{~d}$. for all the contents of the chirograph up to Martinmas in the year of the lord 1292), relates not just to amounts received but for everything owed to the bursar's office. Second, at the close of the account when total expenses have been deducted from total receipts, which in the absence of other adjustments would leave a cash balance to be displayed and counted at the audit, a series of deductions are made including " $£ 1,577.9 \mathrm{~s} .3 \mathrm{~d}$. remaining on the great chirograph." This indicates that this amount was outstanding in the form of arrears at the end of the account, probably including some or all of the arrears due at the start of the account augmented by further arrears which had occurred during the year just past. The amount of arrears actually received is not shown directly as a receipt within the account. In fact, it is not possible to determine what proportion of the receipts relates to current year dues and how much to arrears. An indication as to whether the bursar's office was experiencing improvements or deteriorations in its credit control can be calculated by comparing the opening arrears balance due shown at the start of the account with the closing amount. An increasing balance showed a deterioration and a decreasing balance the converse. In the year 1292-1293, the net increase in arrears was some $£ 811$ which represented $34 \%$ of total new receipts due to be received in that year.

After arrears come the rents due at Martinmas and at Pentecost, tithes, receipts from the sale of wool and from the various courts held by the priory, and a number of loans. The receipts section ends with a grand total of all receipts.

Expenses at first sight appear less well ordered and labeled; only one heading Tallie is given. However, many of the entries appear as account headings in later rolls and, in fact, what is 
shown here is an abbreviated set of expenses showing only the sub-totals of particular expense categories. Thus, we have entries for garderoba, horses, cattle, and traveling expenses, all of which appear regularly as subheadings in later accounts. There follow two sections disclosed and sub-totaled separately - the payments by tally to the cellarer, granator, and manor officials and the payment of debts of the preceding account.

The concluding section again subtracts total expenses from total receipts to state: "Et sic excedunt recepte expensas in mdiiii ${ }^{x x}$ xvi li xis xid" (and so receipts exceed expenses by $£ 1,596.11 \mathrm{~s} .11 \mathrm{~d}$.). In the absence of further adjustments, this figure would have been the increase in cash which the bursar ought to have been able to demonstrate at the audit. However, the following phrase is found: "De quibus se exonerat de" (from which he, the bursar, excuses himself from). Typically, he excuses himself "de mdlvii li ixs iiid remanent in magno cyrograffo" (from $£ 1,557.9 \mathrm{~s} .3 \mathrm{~d}$. remaining on the great chirograph, the roll on which all arrears were recorded). Once all exoneraciones have been deducted (these totaled $£ 1,587.8 \mathrm{~s} .31 / 2 \mathrm{~d}$.), the bursar is said to owe $£ 9.3 \mathrm{~s} .71 / 2 \mathrm{~d}$., of which he could produce only $4 \mathrm{~s} .10 \mathrm{~d}$. remaining in his purse, so he debet de claro (owes clear) $£ 8.18 \mathrm{~s} .9^{1 / 2 \mathrm{~d}}$., which amount was condonantur (forgiven).

The accounts that followed tended to conform to the overall layout described above, with the occasional addition or removal of new or defunct categories of receipt or expense. The use of tighter definitions in the title - the name of the office-bearer, his office, and the period of account including the start and end dates and the length of the period - all illustrate a concern for greater precision. The use of standardized headings, in a consistent order, for specific categories of receipts and expenditure combined with the provision of sub-totals for each heading, and the adoption of a consistent form of balancing off at the end of the account, rendered the accounts more readily comparable from year to year. It also enabled a reviewer to identify more quickly unusual fluctuations and to appreciate more readily the net surplus or deficit position for the year. In this respect, the bursars' accounts of Durham Cathedral Priory mirror some of the changes observed by Harvey in manorial accounts in that diverse forms were superseded by a standardized format, a change also reported by Saunders [1930, p. 152] at Norwich Cathedral Priory. A detailed comparison of accounting at Durham with that done at other houses would shed light on the extent to which monastic houses adopted similar forms or alternatively pursued their own individual standardized models. 


\section{THE FINANCIAL POSITION}

Table 1 gives an indication of the amount of receipts which the bursar was charged with receiving. That amount was always in excess of $£ 1,000$ and at its highest in 1310-1311 reached $£ 6,160$. Total expenses (Table 2) were somewhat less volatile, ranging from just under $£ 1,000$ in $1349-1350$ to $£ 2,610$ in 1310 1311. A simple comparison of the two amounts gives a surplus for each year as illustrated in Table 3 (line 3). The surplus averages $£ 1,302,45 \%$ of average receipts of $£ 2,879$, which would appear to show an extremely healthy financial position with a steady accumulation of cash.

However, if the arrears which the bursar did not receive in the year of the account are subtracted from total receipts due, a much lower level of actual receipts is indicated (Table 3, line 5). After expenditure is deducted from actual receipts, the revised surplus (Table 3 , line 7) is well nigh eradicated, falling to an average of $£ 23$ or $1 \%$ of the revised receipts figure. Indeed, in six of the 13 years examined, receipts and expenditure are so finely matched that the surplus is $£ 4$ or less $(0.25 \%$ of average receipts). The need to adjust for arrears has not always been appreciated. For example McKisack [1959, p. 305] quotes annual receipts of over $£ 3,000$ in the Durham bursar's rolls for 1293, 1295 , and 1297, without deducting the large sums of arrears due from debtors which were carried forward from year to year and included each year within the total receipts figure.

One year (1389-1390) actually reveals a deficit, which also raises the question of how the bursar expended money which he had not received. Goods bought on credit were often reflected within receipts as mutuaciones as well as in the relevant expense category. This deficit may reflect an error in the accounts or a source of cash undisclosed in the accounts. The account itself notes "Et sic superexpendit" (and so he, the bursar, overspent), but no explanation is offered of how this has occurred. It must be assumed that the accounts contain an error or omission, or that the bursar had access to another source of funds, or that some items listed as expenses had not actually been paid, an occurrence noted elsewhere in manorial accounts [Postles, 1981; Noke, 1994].

Why do actual receipts and expenditure appear to be so closely matched? Alternative possible explanations for this are that either receipts were tailored to expenditure and adjusted to match expenditure needs or that expenditure was tailored to the receipts available to be spent. To advance this question, the 


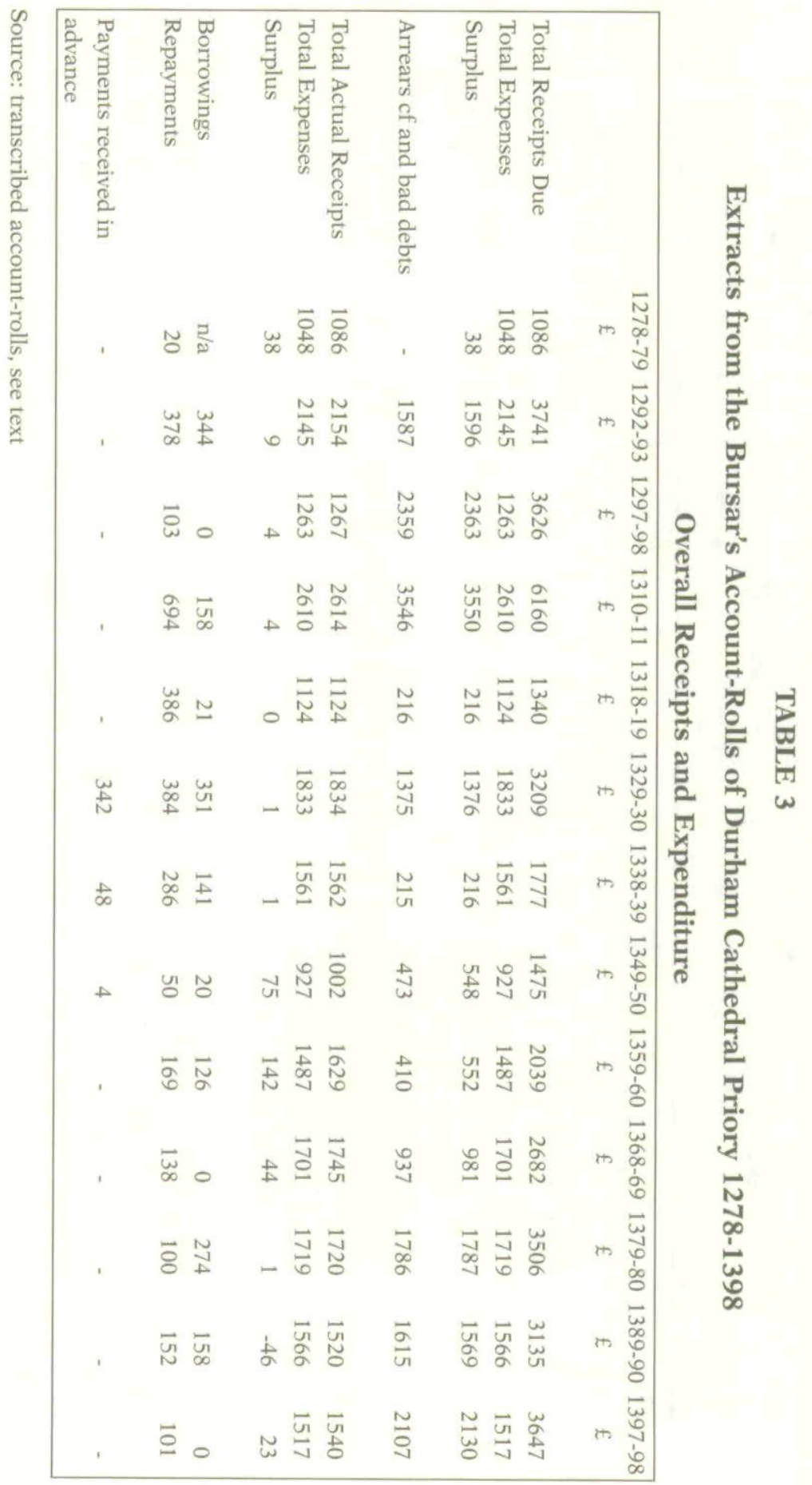


fixed and variable elements of receipts and expenditure need to be considered. Receipts comprised many fixed elements - customary dues and rents, although increments were possible in the latter, and labor dues that could be commuted for a money payment. Tithes depended upon the quantity and quality of the harvest, although again the rights to tithes for a defined period could be sold for a fixed sum. Variable elements, which the bursar could control to a certain extent, included the raising of loans and the sale of the produce of the lands of the priory. The sale of tithes and the produce of the priory estates could also be sold premanibus (in advance) should cash be needed urgently. On the expenditure side, a certain minimum sum would be needed for the running of the house and the sustenance of its members, although this could perhaps be reduced by a concerted effort by the priory to live off its own produce. Investment in land improvement, new stock, and building work could be halted or deferred if necessary. The repayment of debts would reflect the terms of the agreement with the lender.

Over the period $1278-1398$, there is considerable volatility around the average revised receipts $(£ 1,600)$ and expenditure $(£ 1,577)$ levels seen in the accounts selected. The range varies from $£ 1,002$ (1349-1359) to $£ 2,614$ (1310-1311) for receipts and from $£ 927$ to $£ 2,610$ for expenses with the low and high points occurring in the same years as those for receipts. The raising of debt and its repayment may throw some light on whether receipts or expenditure were the predominant force in any one account, the assumption being that increased borrowings and the receipt of income in advance might be necessitated by higher levels of expenditure. Alternatively, higher levels of unassigned receipts might enable the repayment of debt. For example, in $1329-1330$, the borrowing of $£ 351$ and the receipt in advance of $£ 342$ might suggest that the raising of finance was necessary to meet expenditure commitments. Alternatively, the accounts of 1310-1311, which show a net debt repayment of $£ 536$, might indicate that surplus receipts were being used to free the house from debt. It may well be that the alternative scenarios suggested occurred in different years as the fortunes of the priory fluctuated.

Loans appear to have been used for short-term as well as longer-term funding. In the accounts of 1330-1331, for example, can be seen within a single year, both borrowings from and repayments to individual lenders such as John de Vescy and William of Hilton, suggesting these sources were used to cover short-term liquidity needs. The "Recepte fratris Willelmi de 
Hexham" of 1330-1331 may be a chronological listing of items with periodic sub-totals which could have been an attempt to monitor cash flows during the year. An examination of a longer consecutive series of account-rolls, such as those covering the period from 1328-1340, and an analysis of receipts, expenditure, borrowings, and repayments therein may offer further insight into financial planning and cash budgeting at Durham Cathedral Priory. A review of other non-accounting material, such as the priory registers, may also provide background information on the financial state of the priory and the factors which may have led to changes in accounting practices. What can certainly be asserted at this stage, however, is that the finances reflected in the bursars' accounts were finely tuned to ensure that receipts and expenses were on the whole in equilibrium with a small surplus being generated. This fine tuning highlights the importance of adequate financial controls to ensure that income was maximized and that the necessary funds were available to meet expenditure needs.

\section{CONTROLS}

Controls within and around the account-rolls include the separate disclosure of different categories of items, the increasing precision in narrative description, the explanations offered for perceived variations from expected outcomes, balancing off, arithmetic accuracy, auditing, cross referencing to supporting schedules, and the monitoring of debtors and creditors.

The compotus rolls themselves constituted a financial control. The increasingly consistent format of the accounts, the regular order in which items were disclosed, and the use of subheadings and sub-totals for each category of receipts and expenditure made the identification of missing categories easier and facilitated the comparison of amounts between years. Many of the account-rolls were many feet in length, and so it would not have been easy to gain an overall picture of a year's receipts and expenses at a glance. However, there survives a small indenture, some four and a half inches wide (Illustration 4), which comprises a list of all the sub-totals for an account. It has no title, but it evidently relates to the year 1313-1314 because its totals agree with the detailed account-roll for that year. It reduces the account for the year to 45 lines and would have enabled a reviewer to scan all the categories of receipts and expenditure and to form readily an impression of the inflows and outflows.

For a number of years, more than one copy of the account 


\section{ILLUSTRATION 4}

The Summary for 1313-14

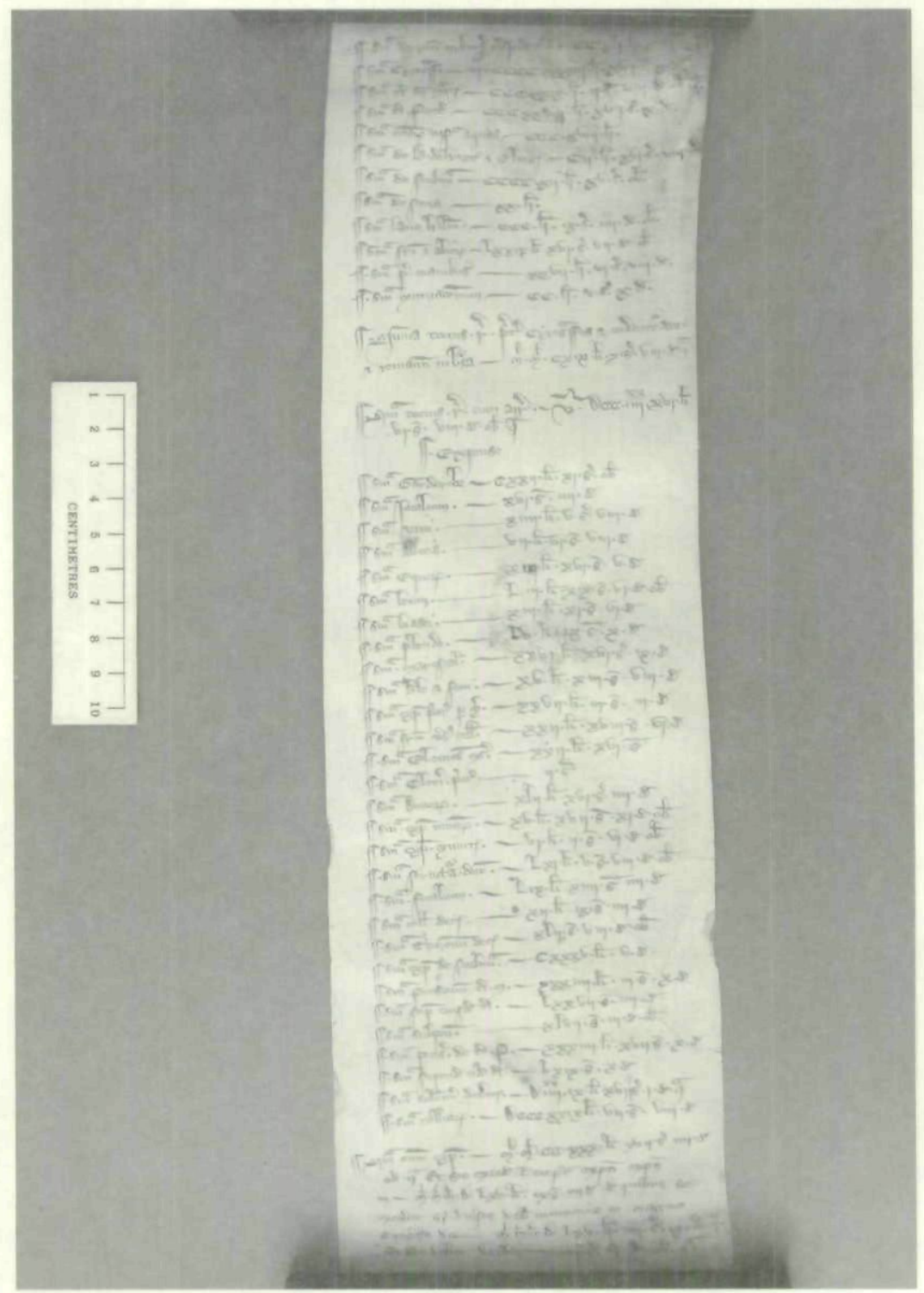

exists. The importance of retaining duplicate copies in different places was realized at an early date. The statutes of Prior Thomas of Melsonby of 1235 dictate that two copies of rent-rolls should be made so that if one be lost, the other might still be 
consulted [Raine, 1839, pp. xxxix-xl]. It seems likely that at least two copies of an account would have been prepared, one to be kept by the officer rendering the account and one to be kept centrally. Where two accounts from the same year survive, they are not always identical. One may contain alterations perhaps made by the bursar, his scribe, or the auditors. Further detailed work may reveal the order in which different versions of the accounts were prepared, and which changes were made by the accountant and which imposed by the auditor.

Within the compotus rolls, it was felt necessary to highlight and disclose separately different categories of receipts and expense. In the 1292-1293 roll, loans to the bursar are included under varie recepte, whereas in later rolls, they are headed mutuaciones. Likewise payments received in advance are given their own heading of premanibus in later accounts rather than being included within the relevant receipts category as happened in some of the earlier accounts. Both of these disclosures were important as they represented prior claims on the future income of the house.

Within individual account categories, there is a trend towards increasing detail and more precise description. The 13101311 account discloses " 45 quarters of oats bought, $£ 7.17$ s.6d.," whereas an account of 1333-1334 provides not only the total price, $£ 18.15$ s., of the 60 quarters of malt bought, but also the price per quarter of $6 \mathrm{~s} .3 \mathrm{~d}$. This enabled auditors to recalculate the total and to assess more readily whether the unit price was reasonable. ${ }^{6}$

For items where there was an apparent shortfall, an explanation is often given on the face of the account. The phrase "et non plus quia" (and not more because) is frequently encountered. Thus, the $1310-1311$ account states " $£ 54.6 \mathrm{~s} .8 \mathrm{~d}$. received from the tithes of the parish of Hesleden and not more because the tithe of Hesleden itself was sold for malt."

The balancing off at the foot of the account-rolls was done very much with the auditors in mind. Illustration 5 provides an example from the account-roll of 1292-1293. A total for payments was subtracted from a total for receipts, and the bursar was expected to be able to produce any surplus remaining or to explain its absence. These exoneraciones (explanations) in the

\footnotetext{
${ }^{6}$ The formulary of Beaulieu Abbey, which served as a guide for auditors, provides a table of standard costs for foodstuffs and clothing which could be compared to actual prices paid and received [Hockey, 1975, pp. 52-55; Harvey, 1999, pp. 26-27].
} 


\section{ILLUSTRATION 5}

\section{The Balancing-Off Section at the Foot of the Account-Roll of 1292-93}

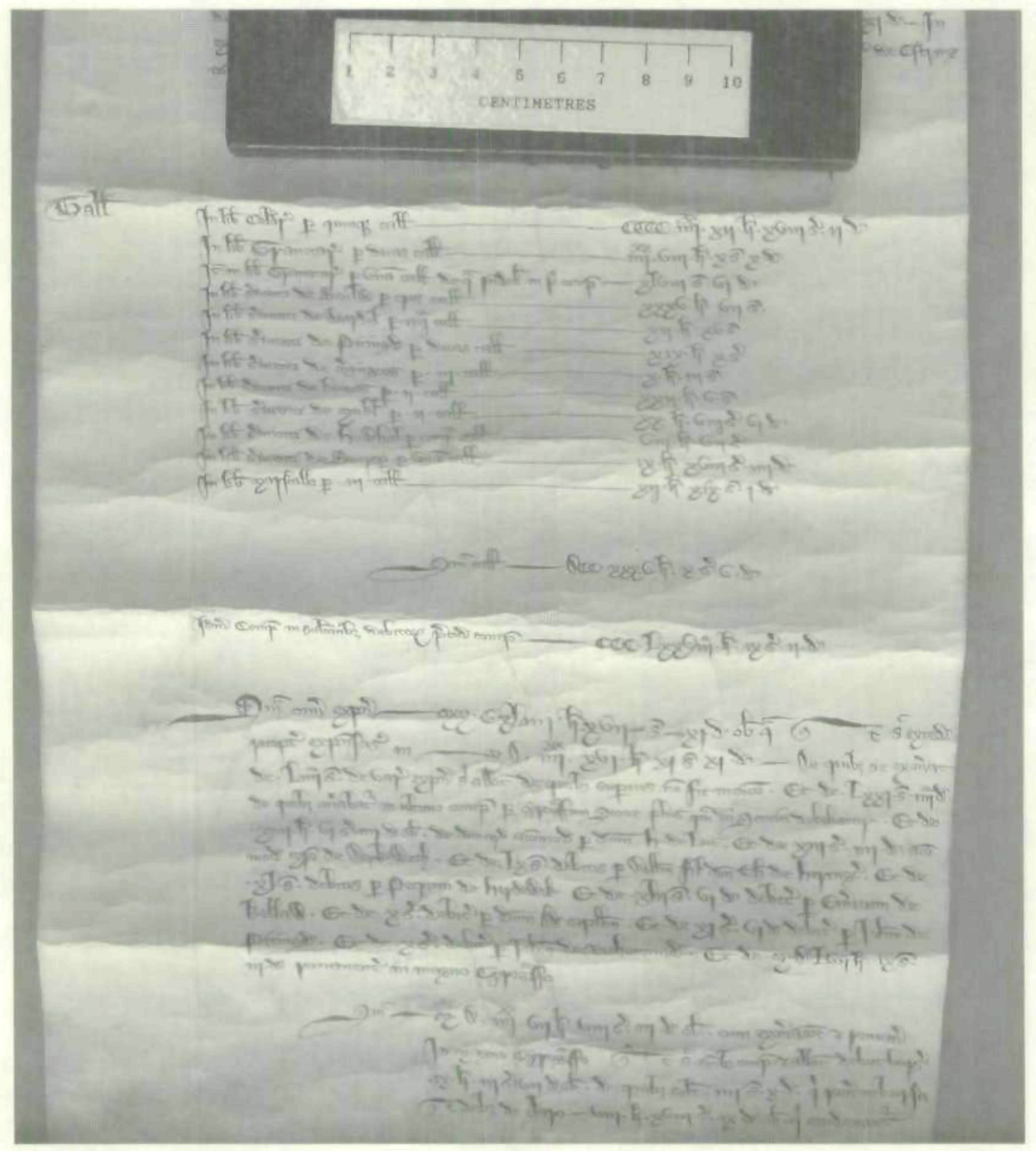

main took the form of arrears of income not actually received.

Once all exoneraciones had been offered and the bursar had acknowledged that he owed a certain amount, any portion of this amount which he could not deliver in cash tended to be condoned. In the 1292-1293 account, this condonacio is for almost $£ 9$, a significant sum, and probably not a level with which rigorous auditors would have been satisfied. It is the largest condonacio found in the accounts surveyed. Later condonaciones are for much smaller amounts - 26s, in 1297-1298, 28s. in $1310-1311,4 s$. in $1318-1319,7 s$. in $1329-1330$, and 5s. in 13381339. Subsequently, condonaciones disappear and any amount 
remaining is carried forward and appears as an opening balance in the receipts section of the following year's account. Thus, at the end of the 1349-1350 account, the bursar, John of Newton, "owes $£ 74.18 \mathrm{~s} .41 / 4 \mathrm{~d}$. for which he will give account in the next account-roll." This is confirmed at the start of the account-roll for 1350-1351: "the same renders account for $£ 74.18 \mathrm{~s} .41 / 4 \mathrm{~d}$. remaining from the closing balance of the account of the preceding year as appears at the foot of the same account." This may be seen as evidence of a tightening-up by the auditors. Properly kept and complete accounts should not require the condonacio of lost revenue or unrecorded expenses.

Arithmetic accuracy was of vital importance in presenting meaningful accounts, and a recalculation of the arithmetic of the balancing-off sections has not revealed any significant errors. However, other studies have revealed frequent arithmetical errors [Threlfall-Holmes, 2005, p. 31]. It could be that remaining accounts are not always the correct final version, or that errors have entered an account during careless copying from a correct version. The 1313-1314 roll includes the purchase of a computatorius for $6 \mathrm{~d}$. There is some doubt as to the precise definition of a computatorius, but it was likely to have been an item to assist in arithmetic calculations, perhaps a table or cloth marked with divisions for calculating totals.

That the accounts should have been audited is not in doubt. Innocent III (1198-1216) required the submission of annual accounts by the superior and officials of a house, and Gregory IX (1227-1241) included the requirement for these to be audited in his statutes of 1235-1237 [Knowles, 1948, pp. 57-58]. The efficacy of the audit would have depended on the knowledge and experience of those auditing. It seems likely that at Durham as in other houses, the accounts were heard and reviewed by a body of senior and experienced monks. The presence or at least knowledge of the prior is indicated by an occasional reference to him at the foot of the account where the condonacio is said to be by his authority. Some priors are said to have had good financial skills. Prior Richard de Hoton (1290-1308), for example, claimed to have augmented the revenues of the priory [Fraser, 1957, pp. 127-128].

The auditors' task was aided by the frequent use of references to subsidiary schedules and other accounts, directing their attention to the source of and breakdown for a figure as well as occasionally providing independent verification of the amount in an account prepared by a third party. In the 1310-1311 account, the phrase visis perticulis (according to the particulars) 
appears some nine times in the expense section. Payments to and receipts from other priory officials could be checked with the amounts disclosed in their accounts. Thus, payments for expenses to the proctors of Norham and Scotland are described as "as shown in the account-roll of the proctor." Payments to the manorial officials tended to be evidenced additionally by tally. The 1292-1293 roll includes "in payment to the manorial official of Pittington by two tallies $£ 19.10$ s."

References to other supporting schedules are illustrated in the account of 1278-1279 which provides very brief details of receipts but directs the reader to the source of the information. Thus, receipts of arrears can be checked to the magnum cirograffum, the amounts due at Martinmas and Pentecost could be vouched to the rotulus sancti martini and the rotulus pentecost. Two such rolls survive from 1270 and 1273 [Lomas and Piper, 1989, pp. 21-29]. Detailed schedules listing the receipts from the sale of tithes survive for many years, and the totals from these correspond to the summarized totals included in the accountrolls.

Much of the emphasis within the accounts is on actual receipts and expenditure. However, the bursars also needed to be able to record and account for transactions which would be settled in future periods. Procedures were developed for the monitoring of both debtors and creditors - the listing, review, and updating of arrears; the writing off of irrecoverable amounts; and the periodic listing of all loans contracted by the house.

In the consideration of the financial position (see above), it was noted that there was a significant difference between the receipts with which a bursar was charged and the amount which he in fact received (the difference arising from opening and closing arrears). The accounts reflect a growing awareness of this distinction in that until 1297-1298, a single sum total of receipts, including arrears brought forward, is given. However, in the account of 1310-1311 and thereafter, two totals are provided at the conclusion of the receipts section of the accounts, one relating to all the receipts except the arrears from prior years and the other including all receipts due including the arrears from prior years.

As can be seen in Tables 2 and 3, the level of arrears exceeded $£ 3,500$ in 1310-1311. The monks as guardians of the assets of St. Cuthbert had a duty to gather and to protect his revenues, and thus, the monitoring of arrears was an important issue [Dobson, 1973, pp. 11-13]. Arrears were recorded on the magnum cirograffum. Between 1292 and 1318, this total appears 
to have been included in the receipts due, which the then bursar was responsible for collecting. The total remaining on the magnum cirograffum at the end of the year was included in the exoneraciones at the end of the account. Such entries can be seen in the accounts of 1292-1293, 1297-1298, and 1310-1311.

The total amount of unreceived income for each compotus shows some striking features (Table 3, line 4) - a steady increase in arrears until 1318-1319, when a massive fall occurs; followed by an increase in 1329-1330, again with a subsequent drop in 1338-1339, after which a more or less steady rise is sustained until the end of the period. These fluctuations reveal changes in accounting practice. Whereas in previous years the bursar was charged with "all the arrears and debts contained in the great chirograph," in 1318-1319, he accounts only for "receipts from the great chirograph" rather than the total amount of arrears. Consequently, at the end of the account under exoneraciones, he includes only the arrears arising from the current year. The reason for the change in accounting practice is not known. Perhaps it was felt that the inclusion of a large amount of old and perhaps irrecoverable debts was distorting the impression given by the accounts. As can be seen in Table 3, arrears dominated the receipts section of the accounts between 1292 and 1311 .

However, after 1318-1319, there then seems to have occurred a reversion to the old accounting practice. By the time of the start of the 1329-1330 account, arrears have built up to $£ 1,309$, and the reference is to "arreragiis contentis in cyrograffo" (arrears contained in the chirograph) which sounds as though a new record of debtors has been opened and that the bursars are once again being charged with the full amount of arrears contained therein. The operation of a new record appears to be confirmed by references in the account of 1335-1336 to receipts "from the old and the new chirographs." From the year 13351336 , there also remains an indenture listing arrears received which shows that arrears as far back as 1315, presumably from the old chirograph, and also from more recent years between 1329 and 1333 had been collected. This suggests that these chirographs of arrears were maintained meticulously and regularly updated.

By the end of the period, the level of arrears has increased significantly. Total arrears are again being included rather than actual receipts. These arrears are identified with the name of the bursar during whose period of office they arose. Thus, the 13961397 account includes arrears from the periods in office of the current bursar, Thomas Lythe, and of his predecessors - John of 
Newburn, Robert of Claxton, Thomas of Corbridge, and "John of Berrington and the others before him." Thus, the policy of whether to include total arrears due, or the more recent arrears, or the actual receipts seems to oscillate, and by the end of the period under review, all arrears which have not been written off appear to be included within receipts once again.

Although arrears appear to have been left on the chirographs for long periods, a new approach of writing off irrecoverable dues seems to emerge in the late 1340s. An indenture headed "Arreragia de quibus non est spes" (arrears for which there is no hope), has survived from 1348. In the 1350-1351 account, new entries appeared in the exoneraciones section - decayed rents and waste rents. These balances are not entered into the head of the next account. Waste and decay were evidently considered irrecoverable as soon as they were identified.

Lists of individually itemized arrears, including arrears ordered by township for halmote court and rental arrears, survive from several years as do schedules itemizing the arrears actually received. These can be agreed with the main account-rolls. Likewise subsidiary schedules detailing the decayed or waste rents for a year survive, which again provide a detailed breakdown of the single figures included within the main account-rolls.

If the monitoring of arrears was important to ensure that all revenues due to St. Cuthbert were collected as far a possible, the monitoring of creditors or of borrowings was equally important to ensure that the house did not become overburdened with debt which it would be unable to repay. It can be seen that given the small surpluses run in most years, borrowings were an important and necessary source of funds. New loans were recorded under mutuaciones within receipts, and repayments were recorded under soluciones debitorum within expenses, but the compotus roll itself did not give an indication of the full extent to which the house was indebted.

Contemporary sources reveal that the house struggled with its level of debt. Prior William of Tanfield (1308-1313) temporarily withdrew assets from obedientiaries and used the proceeds to reduce debts [Cambridge, 1992, pp. 16-19]. An indenture of 1391-1392, evidencing the monies borrowed by Thomas Lythe, bursar, reveals a receipt "from the lord bishop of Durham under the common seal for the payment of old debts, £200." In 1405, it was commented: "The goods, rents and incomes...have been so notoriously wasted that they no longer suffice to pay the usual debts and support the convent in all its necessities" [Dobson, 1973, pp. 250-251]. 
Lists of creditors remain from 1330, 1331, 1333, and 1343. The 1330 schedule starts with debts incurred by the bursar or house, some 70 to 80 items. This is followed by amounts due to manorial officials for the superplusagia (the excess of their expenses over receipts) on their accounts. Finally, debts incurred by the cellarers are listed by cellarer and year from 1307 to 1329 , and a grand total of $£ 1,277.4 \mathrm{~s} \cdot 10 \frac{1}{2} \mathrm{~d}$. is given. This was a significant amount given that the receipts and expenses for the year $1329-1330$ were $£ 1,834$ and $£ 1,833$ respectively.

Debts are not consolidated by creditor. For example, amounts due to the prior appear several times, indicating perhaps that these amounts were taken from a chronological listing rather than from a listing of individual creditors. These debts were carefully monitored as can be illustrated by an amount due to Thomas del Holme for $£ 314.10$ s. which is listed in this 1330 account. Within soluciones debitorum of the 1330-1331 account, a sum of $£ 156$ is paid to del Holme, and in the list of debts compiled at the end of 1331, a new revised balance is shown. Further work on a greater number of accounts may allow a more revealing reconstruction of the net indebtedness of the house, clarify the need to raise debt finance, and identify attempts to control and repay the outstanding debt burden.

\section{CONCLUSION}

This paper has examined a sample of 13 accounts from the bursar's office covering the period 1278-1398. Sources of receipts, types of expenditure, and the format of the accounts have been described. An analysis of the accounts has allowed the calculation of the net surplus or deficit generated each year. This has revealed that once uncollected arrears have been excluded from receipts, the net surplus or deficit was of a very modest amount, and it appears that actual receipts and expenditure were very closely matched, indicating careful monitoring of the cash position. The accounts are largely concerned with receipts and expenditure, but an awareness of balance sheet issues is evidenced by the survival of schedules listing debtors and creditors. These and other schedules, accounts, and records provided a system of cross-checks, which enabled auditors, if they chose, to verify and confirm the accounts presented to them.

The preparation of this paper has also identified a number of areas for further investigation, including an examination of other accounts from obedientiaries, proctors, and manorial officials to ascertain the proportion of the total receipts and expen- 
diture of the house accounted for by the bursar; more detailed comparisons of duplicate accounts to reconstruct their preparation and the audit process; an examination of consecutive accounts to draw out further information on the planning and cash management reflected in the bursars' accounts; a review of other original source material for this period, such as the priory registers, to seek information on the impetus behind accounting changes; and a comparison of accounting procedures at Durham with those of other houses for which records remain, such as Canterbury, Norwich, Westminster, Winchester, and Worcester.

The comment of Dobson [1973, p. 259] that the financial organization at Durham and other houses cries out for a thorough reassessment is still valid. This paper is very much an initial step in an area which offers scope for much further investigation.

\section{REFERENCES}

\section{Primary Sources:}

All manuscripts to which reference is made are to be found in the Durham Cathedral Muniments collection held at No. 5, The College, Durham.

\section{Secondary Sources:}

Cambridge, E. (1992), The Masons and Building Works of Durham Priory 13391539, unpublished Ph.D. thesis, University of Durham.

Chatfield, M. (1977), A History of Accounting Thought (New York: Robert E. Krieger).

Dobson, R.B. (1973), Durham Priory 1400-1450 (Cambridge: Cambridge University Press).

Dodds, B. (2002), Tithe and Agrarian Output between the Tyne and Tees 1350-1450, unpublished Ph.D. thesis, University of Durham.

Fowler, J.T. (ed.) (1898-1901), Extracts from the Account-rolls of the Abbey of Durham, from the original MSS (Surtees Society, Vols. 99, 100, 103).

Fowler, J.T. (ed.) (1903), Rites of Durham (Surtees Society, Vol. 107).

Fraser, C.M. (1957), A History of Anthony Bek, Bishop of Durham 1283-1311 (Oxford: Clarendon Press).

Halcrow, E.M. (1949), The Administration and Agrarian Policy of the Manors of Durham Cathedral Priory, unpublished B.Litt. dissertation, University of Oxford.

Hamilton, S.G. (ed.) (1910), Compotus Rolls of the Priory of Worcester of the $X I V t h$ and $X V$ th Centuries (Worcester Historical Society, Vol. 26).

Harvey, B. (1977), Westminster Abbey and its Estates in the Middle Ages (Oxford: Clarendon Press).

Harvey, B. (2002), The Obedientiaries of Westminster Abbey and their Financial Records (Woodbridge: The Boydell Press).

Harvey, P.D.A. (1999), Manorial Records (London: British Records Association).

Hockey, S.F. (1975), The Account-Book of Beaulieu Abbey (London: Royal Historical Society, Camden 4th Series, Vol. 16).

Jack, S.M. (1966), "An Historical Defence of Single Entry Book-keeping," Abacus, Vol. 2, No. 2: 137-158. 
Kershaw, I. (1973), Bolton Priory: The Economy of a Northern Monastery 12861325 (Oxford: Oxford University Press).

Kitchin, G.W. (1892), Compotus Rolls of the Obedientiaries of St. Swithun's Priory, Winchester (London: Simpkin \& Co).

Knowles, D. (1940), The Monastic Order in England 940-1216 (Cambridge: Cambridge University Press), 1963 revised, 2004 reprint.

Knowles, D. (1948), The Religious Orders in England: Volume I (Cambridge: Cambridge University Press), 1956 reprint.

Knowles, D. (1955), The Religious Orders in England: Volume 2 (Cambridge: Cambridge University Press), 1957 reprint.

Knowles, D. (1969), Christian Monasticism (London: Weidenfeld and Nicholson).

Lomas, R.A. and Piper, A.J. (eds.) (1989), Durham Cathedral Priory Rentals (Surtees Society, Vol. 198).

McKisack, M. (1959), The Fourteenth Century (Oxford: Clarendon Press), 1971 reprint.

Moorman, J.R.H. (1945), Church Life in England in the Thirteenth Century (Cambridge: Cambridge University Press), 1946 reprint.

Noke, C. (1994), "Agency and the Excessus Balance in Manorial Accounts," in Parker, R.H. and Yamey, B.S. (eds.), Accounting History: Some British Contributions (Oxford: Clarendon Press): 139-159.

Piper, A.J. (1992), "Evidence of Accounting and Local Estate Services at Durham, c. 1240," Archives, Vol. 20: 36-39.

Postles, D. (1981), “The 'Excessus' Balance in Manorial Accounts," Bulletin of the Institute of Historical Research, Vol. 54: 105-110.

Postles, D. (1994), "The Perception of Profit before the Leasing of Demesne," in Parker, R.H. and Yamey, B.S. (eds.), Accounting History: Some British Contributions (Oxford: Clarendon Press): 116-138.

Raine, J. (1839), Historiae Dunelmensis Scriptores Tres (Surtees Society, Vol. 9).

Saunders, H.W. (1930), An Introduction to the Obedientiary and Manor Rolls of Norwich Cathedral Priory (Norwich: Jarrold).

Smith, R.A.L. (1943), Canterbury Cathedral Priory: A Study in Monastic Administration (Cambridge: Cambridge University Press).

Snape, R.H. (1926), English Monastic Finances in the Later Middle Ages (Cambridge: Cambridge University Press).

Stone, E. (1962), "Profit-and-Loss Accountancy at Norwich Cathedral Priory," Transactions of the Royal Historical Society, 5th Series, Vol. 12: 25-48.

Threlfall-Holmes, M. (2005), Monks and Markets: Durham Cathedral Priory 14601520 (Oxford: Oxford University Press).

Wilson, J.M. and Gordon, C. (eds.) (1908), Early Compotus Rolls of the Priory of Worcester (Worcester Historical Society, Vol. 23). 
Copyright of Accounting Historians Journal is the property of Academy of Accounting Historians and its content may not be copied or emailed to multiple sites or posted to a listserv without the copyright holder's express written permission. However, users may print, download, or email articles for individual use. 